\title{
Probability distribution of rainfall for Kolhapur region
}

\section{GAURI MEHENDALE, RUPESH SAWANT, DIGAMBER MOHITE, VIDYA DESHMUKH AND SANGITA SHINDE}

Article Chronicle : Received: 10.11.2014; Accepted : 20.11.2014
Key Words : Distribution of rainfall, Hydrology, Log pearson type IV distribution, $\log$ normal distribution, Log pearson type III distribution
SUMMARY : Rainfall is one of the most important natural input resources to crop production and its occurrence and distribution is erratic, temporal and spatial variations in nature. Most of the hydrological events occurring as natural phenomena are observed only once. One of the important problem in hydrology deals with the interpreting past records of hydrological event in terms of future probabilities of occurrence. Rainfall analysis is a prerequisite for proper designing of any soil and water conservation structure. Daily rainfall data will be collected from Department of Agronomy, College of Agriculture, Kolhapur for the year 2012-13. For this study Normal, Log-normal and Gumbel distributions of probability are used. From the analysis it was concluded that, Log- pearson type III distribution was found to be good for probability distribution of rainfall in the Kolhapur region.

HOW TO CITE THIS ARTICLE : Mehendale, Gauri, Sawant, Rupesh, Mohite, Digamber, Deshmukh, Vidya and Shinde, Sangita (2014). Probability distribution of rainfall for Kolhapur region. Asian J. Environ. Sci., 9(2): 80-86.
Author for correspondence :

\section{GAURI MEHENDALE}

Department of Soil and Water Conservation Engineering, Dr. D.Y. Patil College of Agricultural Engineering and Technology, KOLHAPUR (M.S.) INDIA Email: gauri277@gmail. com

See end of the article for Coopted authors' 